\title{
Significance of Foliar Spray with Some Growth Promoting Rhizobacteria and Some Natural Biostimulants on Yield and Quality of Cucumber Plant
}

\section{KH. Farrag, A. A. Omara* and M. N. E-Said*}

Vegetable Res. Dept., Horticulture Research Institute and "Soil, Water and Environ. Research Institute, Agricultural Research Centre, Cairo, Egypt

7 WO field experiments were conducted at El-Kafr El-Gedid Village, Kafr El-Sheikh Governorate, Egypt, during summer seasons of 2012-2013 and 2013-2014. The study is an attempt to improve vegetative growth, yield and quality of cucumber "hybrid Prince" using some growth promoting rhizobacteria and/or biostimulants. Cucumber plants were sprayed with seaweed extract $(2.5 \mathrm{~g} / \mathrm{L})$, fishmeal extract $(10 \mathrm{~g} / \mathrm{L})$, Azospirillum liquid culture $(15$ $\mathrm{ml} / \mathrm{L})$, Trichoderma liquid culture $(15 \mathrm{ml} / \mathrm{L})$, compost tea $(65 \mathrm{ml} / \mathrm{L})$ and their mixture compared to control (tap water).The spray with the different materials were carried out after 15 days of transplanting, then two times later at 15 days intervals. The application with the different spray materials alone or mixed attained significant increases in vegetative growth (leaf area $\left(\mathrm{cm}^{2}\right)$, leaves dry matter percentage and number of female flowers/plant), fruit length $(\mathrm{cm})$, fruit diameter $(\mathrm{cm})$, early and total fruit yield (t/fed.) over water sprayed control plants. Furthermore, the spray materials positively increased total soluble solids, N, P and K percentages in leaves as well as chlorophyll content. Also, the mixture treatment gave the highest net return L.E/fed. (6925).

The mixture was the best in this context, so that, spraying cucumber plants with the mixture treatment three times is recommended to improve yield and quality of the plant.

Keywords: Cucumber, Seaweed, Fishmeal, Azospirillum, Trichoderma, Compost tea.

Cucumber (Cucumis sativus L) is an important vegetable and one of the most popular members of the cucurbitaceae family (Thoa, 1998). It is thought to be one of the oldest vegetables cultivated by man with historical records dating back 5,000 years (Wehner and Guner, 2004).

In recent years, the world focused his attention to minimize environmental pollution and human health impacts, by reducing the use of synthetic fertilizers and chemicals in crops production. Especially, vegetables which eat freshly eaten (IFAOM/SOEL, 2000 and FAO/TTC, 2001). 
Compost tea extract has been defined simply as a liquid extract from composted material that may contain organic and inorganic soluble nutrients, and a large number of microorganisms including bacteria and fungi (ROU, 2003b). Compost tea is manufactured and used on a wide range of crops such as vegetables, fruit, vines, cotton, cereals, and trees. The production and application of compost tea is primarily focused on disease suppression, supplementing plant nutrients and increasing soil microbiology to improve soil structure, water percolation/retention, rooting depth and consequently improved plant growth.

Seaweed extract application for different crops is consider a great importance for its high contents from organic matter, micro elements ( $\mathrm{Fe}, \mathrm{Cu}, \mathrm{Zn}, \mathrm{Co}, \mathrm{Mo}$, $\mathrm{Mn}$, and $\mathrm{Ni}$ ), vitamins and amino acids and also, rich in growth regulators such as auxins, cytokinin and gibberellins (Khan et al., 2009). The beneficial effect of seaweed extract is a result of many components that may work synergistically at different concentrations (Fornes et al., 2002).

Fishmeal fertilizers, also, are excellent sources of nutrition for soils and plants whereas fishs contain the full spectrum of nutrients. Plants rapidly respond to it and grow vigorously when regularly fertilized with fish fertilizers.

Azospirillum brasilense is one of the best bacterial biostimulants which release plant phytohormones, amino acids, antioxidants, siderofores and antibiotic in addition to fixing atmospheric nitrogen in the rhizosphere or phyllosphere (Martinez-Viveros et al., 2010). The effect of Trichoderma viride on growth of plants can increase percent of germination and produce some metabolites of the antagonistic microbes which stimulate plant growth. Such metabolites may include antibiotics, siderophores, hydrogen cyanide, enzymes, or growth stimulating hormones such as auxins and gibberellins and some of the metabolites facilitate transformation of unavailable mineral and organic compounds into available forms to the plant (Haikal, 2008).

Hence, the goal of the current research was to improve vegetative growth and yield as well as fruits quality of cucumber plants using some natural extracts which nontoxic, environmentally friendly, organic and costless.

\section{Materials and Methods}

Two field experiments were conducted at El-Kafr El-Gedid Village, Kafr ElSheikh Governorate, Egypt, during summer seasons of 2012-2013 and 20132014. This work is an attempt to study the response of cucumber plants (Cucumis sativus cv. Prince Hybrid), to foliar spray application with some biostimulants. Also, to study the possibility of using such costless and safety methods for maximizing growth, productivity and fruit quality. Plants were sprayed three times at $20 \mathrm{~L}$ feddan with diluted 1:5. The first one was at 15 days after transplanting and repeated each 15 days by intervals. All cultural practices for growing cucumber plants were performed as recommended by Egyptian Ministry of Agriculture for mineral fertilizers. Treatments were as follows:

Egypt. J. Hort. Vol. 42, No. 1 (2015) 
- Compost tea extract at $65 \mathrm{ml} / \mathrm{L}$.

- Seaweed extract at $2.5 \mathrm{~g} / \mathrm{L}$.

- Fishmeal extract at $10 \mathrm{~g} / \mathrm{L}$.

- Azospirillum brasilense liquid culture at $15 \mathrm{ml} / \mathrm{L}$. $\left(1 \times 10^{9} \mathrm{cfu} / \mathrm{ml}^{-1}\right)$.

- Trichoderma viride liquid culture at $15 \mathrm{ml} / \mathrm{L}$. (1× $10^{6}$ spores $\left./ \mathrm{ml}^{-1}\right)$.

- Mixture. (Which contains, Azospirillum, Trichoderma, seaweed extract and fishmeal extract were added with the above mentioned rates to the filtrated final compost tea).

- Control (Tap water).

The previous treatments were arranged in four replicates using complete randomized block design and the plot area was 20 square meter, the spacing between plants was $40 \mathrm{~cm}$. ( $\left(1 \mathrm{~m}^{2}\right.$ included 2.5 plant $)$. The experimental soil analysis is shown in Table 1 .

TABLE 1. Some physical, chemical and biological characteristics of the experimental soil.

\begin{tabular}{|c|c|c|c|c|c|c|c|c|c|c|}
\hline \multicolumn{2}{|c|}{ Clay \% } & \multicolumn{2}{|c|}{ Silt \% } & Sand \% & & \multicolumn{2}{|c|}{ Texture } & pH & $\begin{array}{c}\text { EC } \\
\left(\text { ds. } m^{-1}\right)\end{array}$ & $\begin{array}{c}\text { O.M } \\
(\%)\end{array}$ \\
\hline \multicolumn{2}{|c|}{18.15} & \multicolumn{2}{|c|}{36.50} & 46.35 & & \multicolumn{2}{|c|}{ Loam } & 7.82 & 0.190 & 1.66 \\
\hline \multicolumn{4}{|c|}{ Cations (mg/L) } & \multicolumn{4}{|c|}{ Anions (mg/L) } & \multicolumn{3}{|c|}{ Macro-nutrient (ppm) } \\
\hline $\mathrm{Na}+$ & $\mathrm{Ca}++$ & $\mathbf{M g}^{++}$ & $\mathbf{K}^{+}$ & CO3-- & HCO3- & Cl- & SO4- & $\mathbf{N}$ & $\mathbf{P}$ & $\mathbf{K}$ \\
\hline 0.12 & 0.83 & 0.47 & 0.57 & - & 1.00 & 0.81 & 0.18 & 7.10 & 6.16 & 371 \\
\hline \multicolumn{4}{|c|}{$\begin{array}{l}\text { Total count of bacteria } \\
\text { (cfu/g dry weight) }\end{array}$} & \multicolumn{4}{|c|}{$\begin{array}{l}\text { Total count of fungi } \\
\text { (cfu/g dry weight) }\end{array}$} & \multicolumn{3}{|c|}{$\begin{array}{c}\text { Total count of actinomycetes } \\
\text { (cfu/g dry weight) }\end{array}$} \\
\hline \multicolumn{4}{|c|}{$185 \times 10^{7}$} & \multicolumn{4}{|c|}{$77 \times 10^{5}$} & \multicolumn{3}{|c|}{$68 \times 10^{5}$} \\
\hline
\end{tabular}

Physical, chemical and biological analyses of soil were determined by Department of Soil Chemistry and Department of Agriculture Microbiology, Soil, Water and Environment Research Institute, Agric. Res. Center.

\section{Compost tea extract}

The stock solution of compost tea was prepared in Bacteriology Lab., Soil, Water and Environment Research Institute, Sakha Agricultural Research Station by soaking $5 \mathrm{Kg}$ of matured compost with $0.5 \mathrm{~L}$ molass in $50 \mathrm{~L}$ of dechlorated water for three days in a polyethelen compost tea machine $(100 \mathrm{~L} /$ capacity $)$ with continuous areation during the period of soaking by an air pump with using PVC pipe that was dipped in it (Ingham, 2005). After soaking time, the liquid mixture was filtrated by plastic net.

\section{Seaweed extract}

Seaweed extract product imported by Techno Green Comp. Group, Cairo, Egypt. The stock solution of seaweed extract was prepared in Bacteriology Lab., Soil, Water and Environment Research Institute, Sakha Agricultural Research 
Station by dissolving $2.5 \mathrm{~g} / \mathrm{L}$ of dechlorated water for two days in a glass stock (20 liter) with continuous areation using air pump. Its constituent was as follows:

\begin{tabular}{|c|c|c|c|}
\hline $\mathbf{P H}$ & $9-11$ & $\mathbf{K}_{\mathbf{2}} \mathbf{O}(\boldsymbol{\%})$ & $\geq 18.0$ \\
\hline $\begin{array}{c}\text { Organic Matter } \\
(\%)\end{array}$ & $40.0-50.0$ & Alginic Acid (\%) & $\geq 10$ \\
\hline $\begin{array}{c}\text { Total Nitrogen } \\
(\%)\end{array}$ & $\geq 1.0$ & $\begin{array}{c}\text { Cytokinin \& } \\
\text { Gebberellin }\end{array}$ & $600 \mathrm{ppm}$ \\
\hline $\mathbf{P}_{\mathbf{2}} \mathbf{O}_{\mathbf{5}}(\boldsymbol{\%})$ & $\geq 6.0$ & Dry Matter (\%) & $\geq 95.0$ \\
\hline Other Ingredients: & $\begin{array}{c}\mathrm{S}, \mathrm{Mg}, \mathrm{Ca}, \mathrm{Na}, \text { Alginic acid, Amino acid, Mannitol, } \\
\text { Auxin and Natural Plant Hormones. }\end{array}$ \\
\hline
\end{tabular}

\section{Fishmeal extract}

Fishmeal extract product was prepared in Bacteriology Lab., Soil, Water and Environment Research Institute, Sakha Agricultural Research Station by dissolving $10 \mathrm{~g}$ fish powder /L of dechlorated water for two days in a glass stock (20 liter) with continuous areation using air pump.

\section{Azospirillum brasilense liquid culture}

Azospirillum semi solid Döbereiner medium (Döbereiner et al., 1976) contained (g/L of distilled water): Malic acid, 5.0, $\mathrm{KH}_{2} \mathrm{PO}_{4}, 0.4, \mathrm{~K}_{2} \mathrm{HPO}_{4}, 0.1$, $\mathrm{MgSO}_{4} .7 \mathrm{H}_{2} \mathrm{O}, 0.2, \mathrm{NaCl}, 0.1, \mathrm{CaCl}_{2} .7 \mathrm{H}_{2} \mathrm{O}$. 0.02, $\mathrm{FeCl}_{3} .6 \mathrm{H}_{2} \mathrm{O}, 0.01, \mathrm{NaMoO}_{4}$. $2 \mathrm{H}_{2} \mathrm{O}, 0.002$, Agar, 1.75. Azospirillum brasilense was grown up for 3 days at $30^{\circ} \mathrm{C}$.

\section{Trichoderma viride liquid culture}

Potato dextrose agar medium (Tsao, 1970) contained ( $\mathrm{g} / \mathrm{L}$ of distilled water): Extract of $200 \mathrm{~g}$ potatoes, dextrose, 20, Yeast extract, 0.5 , Distilled water up to final volume of $1000 \mathrm{ml}$, Agar, 15-20.

$200 \mathrm{~g}$ potatoes were peeled, sliced and boiled water in $500 \mathrm{ml}$ distilled water until soften and then filtered. The filtrate (extract) was used for medium preparation.

Trichoderma viride was grown up for 5 days at $30^{\circ} \mathrm{C}$.

Experimental parameters

Vegetative growth

- Leaf area $\left(\mathrm{cm}^{2}\right)$ of the sixth leaf from the meristemic top of the main stem.

Ten plants of each treatment and the area was determined by using L1-3000Portable Area Meter (PAM).

- Leaf dry matter (\%).

- Number of female flowers / plant.

\section{Fruit yield}

- Early yield (t/fed.): Fruits of first eight harvests from each treatment were weighted to calculate the early yield per feddan. 
- Total yield (t/fed.): All fruits harvested from each treatment along the harvesting period were weighted to calculate the total yield per feddan.

- Fruit characteristics: Ten fruits from each treatment through 8 picking were taken randomly for determining average fruit characters as follows:

- Fruit weight $(\mathrm{g})$. - Number of fruits/ feddan.

- Fruit length $(\mathrm{cm})$. - Fruit diameter $(\mathrm{cm})$.

- Total soluble solids in fruits (TSS) \%.

\section{Chemical constituents}

- Total nitrogen, phosphorus and potassium were determined in the dry matter of leaves according to the methods described by Pregl (1945), Trough and Mager (1939) and Browns and Lilliland (1946) respectively.

- Total chlorophyll: Total chlorophyll was determined by Minolta chlorophyll metter SPAD- 502 in the felid.

\section{Fruit quality}

Included, average fruit length $(\mathrm{cm})$, and fruit diameter $(\mathrm{cm})$. Total soluble solids (TSS \%) was determined in fruit juice by a hand refractometer according to A.O.A.C. (1965).

Fruit characteristics were determined in fruits picked in the same day (which its flowers were previously labeled at the same opening day).

\section{Microbial estimations}

It was estimated by counting total count of bacteria, fungi and actinomycetes according to Allen (1959).

\section{Statistical analysis}

All data obtained during both seasons of study were subjected to analysis of variance and significant differences among means were determined at 5\% level of significance according to (Snedecor and Corchran, 1972).

\section{Results and Discussion}

\section{Vegetative growth}

Data of Table 2 indicated that foliar spray cucumber plants with some biostimulants (compost tea, fishmeal extract, and seaweed extract) and/or microorganisms i.e. Azospirillum brasilense and Trichoderma viride led to improvement for leaf area, number of female flowers and leaves dry matter percentage. The foliar spray with compost tea attained significant increaments for these characteristics through both growing seasons, followed by spray with liquid culture of Azospirillum, then fishmeal extract and finally liquid culture of Trichoderma. However, spray with the mixture of compost tea with the other studied materials showed the highest increases at all, and the differences were significant over control plants, which gave 93.00, 37.50 and 24.23 at the first 
season (2013) and 95.25, 38.50 and 25.78 at the second (2014) respectively, compared to 61.50, 17.00 and 15.81 at season 2013 and $63.25,20.00$ and 17.44 at season 2014 for control treatment. These are in agreement with those results obtained by Chamangasht et al., (2012) they indicated that biostimulants (the mixture of Azotobacter, Azospirillum, Pseudomonas and compost tea) can improve plant growth and yield of lettuce. Also these are in agreement with Abou-El-Hassan \& Desoky (2013) they reported that using compost tea of compost increased the vegetative properties of lettuce plants. Also, In this regard, (Fathy et al., 2000 and El-Desouky et al., 2011) found that spraying tomato plants with biostimulants significantly increased plant length, leaves No./plant, branching and leaf area / plant.

TABLE 2. Effect of foliar spray with plant growth promoting rhizobacteria and/or biostimulants on vegetative growth characters of cucumber plants.

\begin{tabular}{|l|c|c|c|c|c|c|}
\hline \multirow{3}{*}{ Treatments } & \multicolumn{2}{|c|}{$\begin{array}{c}\text { Leaf area } \\
\text { (cm2) }\end{array}$} & $\begin{array}{c}\text { Leaves dry matter } \\
(\mathbf{\%})\end{array}$ & $\begin{array}{c}\text { Number of female } \\
\text { flowers/plant }\end{array}$ \\
\cline { 2 - 7 } & \multicolumn{7}{|c|}{ Seasons } \\
\cline { 2 - 7 } & $\mathbf{2 0 1 3}$ & $\mathbf{2 0 1 4}$ & $\mathbf{2 0 1 3}$ & $\mathbf{2 0 1 4}$ & $\mathbf{2 0 1 3}$ & $\mathbf{2 0 1 4}$ \\
\hline Compost tea extract & 82.50 & 85.00 & 21.89 & 23.32 & 34.25 & 33.75 \\
\hline Seaweed extract & 81.00 & 81.25 & 19.25 & 21.22 & 22.00 & 24.50 \\
\hline Fishmeal extract & 76.00 & 77.75 & 18.36 & 19.19 & 20.75 & 23.75 \\
\hline Azospirillum liquid & 80.75 & 81.25 & 21.00 & 21.94 & 27.25 & 28.50 \\
\hline Trichoderma liquid & 65.00 & 70.25 & 17.24 & 18.13 & 19.50 & 22.00 \\
\hline Mixture & 93.00 & 95.25 & 24.23 & 25.78 & 37.50 & 38.50 \\
\hline Control & 61.50 & 63.25 & 15.81 & 17.44 & 17.00 & 20.00 \\
\hline F. test & $* *$ & $* *$ & $* *$ & $* *$ & $* *$ & $* *$ \\
\hline L.S.D 5\% & 3.22 & 2.37 & 1.13 & 1.08 & 1.29 & 2.04 \\
\hline
\end{tabular}

Fruit yield

Data presented in Table 3 showed that the foliar spray with biostimulants, microorganisms and/or their mixture significantly increased fruit weight $(\mathrm{g})$, early fruits yield ( $t / f e d$.$) and total fruits yield ( t / f e d$.$) of cucumber plants. The$ results revealed that foliar spray with the mixture gave the highest increases over control (tap water spray), which were highly significant. These values recorded 156.00, 4.87 and 14.75 at season 2013 and 160.25, 4.85 and 15.44 at 2014, then the spray with compost tea which, also, gave highly significant increases over control. It attained $151.25,3.80$ and 12.90 at season 2013 and $154.75,3.90$ and 13.13 at season of 2014 compared to $95.00,2.18$ and 9.49 at season 2013 and $104.25,2.28$ and 9.96 respectively. These results could be explained as a reflection of the beneficial effects of some growth promoting rhizobacteria and compost tea that contains many macro and micro nutrients in available form, natural hormones, vitamins and antioxidants which be available for plant and so reflect on plant growth and its composition (Abbasi et al., 2002, Biocycle, 2004 and Meshref et al., 2010) that led to improve number of fruits and total yield of cucumber plants. 
TABLE 3. Effect of foliar spray with plant growth promoting rhizobacteria and/or biostimulants on yield of cucumber plants.

\begin{tabular}{|l|c|c|c|c|c|c|}
\hline \multirow{3}{*}{ Treatments } & \multicolumn{2}{|c|}{$\begin{array}{c}\text { Average fruit } \\
\text { weight }(\mathbf{g})\end{array}$} & $\begin{array}{c}\text { Early yield } \\
\text { (t/feddan) }\end{array}$ & \multicolumn{2}{c|}{$\begin{array}{c}\text { Total yield } \\
\text { (t/feddan) }\end{array}$} \\
\cline { 2 - 8 } & \multicolumn{7}{|c|}{ Seasons } \\
\cline { 2 - 8 } & $\mathbf{2 0 1 3}$ & $\mathbf{2 0 1 4}$ & $\mathbf{2 0 1 3}$ & $\mathbf{2 0 1 4}$ & $\mathbf{2 0 1 3}$ & $\mathbf{2 0 1 4}$ \\
\hline Compost tea extract & 151.25 & 154.75 & 3.80 & 3.90 & 12.9 & 13.13 \\
\hline Seaweed extract & 141.50 & 145.25 & 2.65 & 2.79 & 10.6 & 10.98 \\
\hline Fishmeal extract & 121.75 & 131.00 & 2.54 & 2.59 & 10.15 & 10.80 \\
\hline Azospirillum liquid & 149.00 & 152.25 & 3.28 & 3.26 & 12.15 & 12.25 \\
\hline Trichoderma liquid & 107.50 & 114.25 & 2.45 & 2.54 & 9.80 & 10.64 \\
\hline Mixture & 156.00 & 160.25 & 4.87 & 4.85 & 14.75 & 15.44 \\
\hline Control & 95.00 & 104.25 & 2.18 & 2.28 & 9.49 & 9.96 \\
\hline F. test & $* *$ & $* *$ & $* *$ & $* *$ & $* *$ & $* *$ \\
\hline L.S.D 5\% & 4.001 & 3.78 & 0.23 & 0.17 & 0.65 & 0.56 \\
\hline
\end{tabular}

\section{Chemical constituents}

The foliar spray with microorganisms, biostimulants and their mixture led to consistent increases in chlorophyll values (SPAD units), N, P and K \% over the treatment of tap water spray (control), through the two studying seasons (Table 4). The mixture treatment gave the highest increases over control, which exhibited 4.35, 4.77, 0.70 and 5.37 at season 2013 compared to treatment of control that gave 31.15, 2.80, 0.30 and 2.55 respectively. Most differences than control were significant. Results of season 2014 gave a similar trend. Similarly, Masarirambi et al. (2010) reported that there was relatively higher macro and micronutrients content in lettuce plants produced by foliar spray with biostimulants than those grown with conventional fertilizers. These effects might be due to the beneficial effects of compost tea and PGPR that increase supply of macro and micro nutrients in available form for plants. Also, Fish fertilizers contain significant quantities of protein nitrogen as well as a healthy balance of all 18 nutrients known to be significant for crop growth. All of these mineral nutrients are in protein chelated forms which are usable by the crops and additionally are resistant to loss from leaching. Fish also contains more than 60 other trace minerals which have positive effects on soil biology and crop health. As were suggested by Meshref et al. (2010) and Saharan \& Nehra (2011).

(Fathy et al., 2000 and El-Desouky et al., 2011) reported that spraying tomato plants with biostimulants significantly increased mineral content $(\mathrm{P}, \mathrm{K}$, $\mathrm{Ca}$ and $\mathrm{Mg}$ ), carbohydrate, sugar contents and total chlorophyll.

Shehata et al. (2011) mentioned that spraying growth promoting rhizobacteria significantly increased $\mathrm{N}, \mathrm{P}$, and $\mathrm{K}$ and content of leaves of celeriac plant. 
TABLE 4. Effect of foliar spray with plant growth promoting rhizobacteria and/or biostimulants on some chemical content for leaves of cucumber plants.

\begin{tabular}{|c|c|c|c|c|c|c|c|c|}
\hline \multirow[t]{3}{*}{ Treatments } & \multicolumn{2}{|c|}{$\begin{array}{c}\text { Chlorophyll } \\
\text { content (SPAD } \\
\text { unit) } \\
\end{array}$} & \multicolumn{2}{|c|}{$\mathbf{N}(\%)$} & \multicolumn{2}{|c|}{$\mathbf{P}(\%)$} & \multicolumn{2}{|c|}{$\mathbf{K}(\%)$} \\
\hline & \multicolumn{8}{|c|}{ Seasons } \\
\hline & 2013 & 2014 & 2013 & 2014 & 2013 & 2014 & 2013 & 2014 \\
\hline Compost tea extract & 36.00 & 38.47 & 4.35 & 4.42 & 0.68 & 0.70 & 4.90 & 4.97 \\
\hline Seaweed extract & 35.80 & 36.82 & 4.07 & 4.10 & 0.58 & 0.60 & 4.37 & 4.57 \\
\hline Fishmeal extract & 35.30 & 35.20 & 3.65 & 3.75 & 0.47 & 0.51 & 4.12 & 4.40 \\
\hline Azospirillum liquid & 31.67 & 31.37 & 4.47 & 4.30 & 0.59 & 0.56 & 4.97 & 4.90 \\
\hline Trichoderma liquid & 31.97 & 32.50 & 3.87 & 3.95 & 0.47 & 0.48 & 4.02 & 4.02 \\
\hline Mixture & 40.35 & 40.00 & 4.77 & 4.85 & 0.70 & 0.71 & 5.37 & 5.55 \\
\hline Control & 31.15 & 30.87 & 2.80 & 3.02 & 0.30 & 0.36 & 2.55 & 3.42 \\
\hline F. test & $* *$ & $* *$ & $* *$ & $* *$ & $* *$ & $* *$ & $* *$ & $* *$ \\
\hline L.S.D $5 \%$ & 2.3 & 1.47 & 0.31 & 0.25 & 0.04 & 0.03 & 0.29 & 0.31 \\
\hline
\end{tabular}

\section{Fruit quality}

Data of Table 5 exhibited some of quality characteristics of cucumber fruits i.e. T.S.S \%, fruit length $(\mathrm{cm})$ and fruit diameter $(\mathrm{cm})$. All the studied foliar application treatments gave increaments over tap water spray treatment (control), through the two studying seasons. The treatment which attained the highest effect was the spray with the mixture followed by compost tea then Azospirillum, while the spray with the diluted liquid culture of Trichoderma gave the lowest positive effects. Mostly, variation between revealed significances. Results of season 2014 had the same trend of those of 2013. (Abou-El-Hassan et al., 2014) showed that addition of plant growth promoting rhizobacteria (PGPR) or compost tea to produce good yield and quality of cucumber plants under sandy soil. Similarly, spray of fruit trees with componds containing amino acids, plant phytohormones, humate, $\mathrm{N}, \mathrm{P}, \mathrm{K}$ and some microelements contribute in improving tree growth and quality of yield (Eissa, 2003). Likewise, foliar application with some PGPR types gave results similar to the action of these treatments (Nour El-Din, 2006).

\section{Economic estimation}

Data of Table 6 included costs of cultivation of one feddan of cucumber (fixed and changed), price of the produced fruits (L.E) and the net of feddan at each foliar spray treatment. The control treatment (tap water spray) gave the lowest net return (238 L.E. /fed.), while the treatment of spray with the mixture of biostimulants and microorganisms attained the highest net return $(6925$ L.E. /fed.) followed by the treatment of compost tea (4375 L.E./fed.) then the treatment of Azospirillum which gave 3200 L.E./fed. 
TABLE 5. Effect of foliar spray with plant growth promoting rhizobacteria and biostimulants on fruit quality of cucumber plants.

\begin{tabular}{|l|c|c|c|c|c|c|}
\hline \multirow{2}{*}{ Treatments } & \multicolumn{7}{|c|}{$\begin{array}{c}\text { T.S.S in } \\
\text { fruits (\%) }\end{array}$} & \multicolumn{2}{|c|}{$\begin{array}{c}\text { Average fruit length } \\
\text { (cm) }\end{array}$} & $\begin{array}{c}\text { Average fruit } \\
\text { diameter (cm) }\end{array}$ \\
\cline { 2 - 8 } & \multicolumn{7}{|c|}{ Seasons } \\
\cline { 2 - 8 } & $\mathbf{2 0 1 3}$ & $\mathbf{2 0 1 4}$ & $\mathbf{2 0 1 3}$ & $\mathbf{2 0 1 4}$ & $\mathbf{2 0 1 3}$ & $\mathbf{2 0 1 4}$ \\
\hline Compost tea extract & 4.87 & 4.92 & 13.72 & 13.82 & 3.50 & 3.47 \\
\hline Seaweed extract & 4.57 & 4.75 & 12.52 & 12.92 & 3.07 & 3.17 \\
\hline Fishmeal extract & 4.50 & 4.52 & 11.32 & 12.10 & 2.95 & 3.02 \\
\hline Azospirillum liquid & 4.22 & 4.30 & 13.25 & 13.32 & 3.25 & 3.22 \\
\hline Trichoderma liquid & 3.97 & 4.12 & 11.32 & 11.60 & 2.77 & 3.52 \\
\hline Mixture & 5.25 & 5.47 & 14.12 & 14.87 & 3.80 & 3.85 \\
\hline Control & 4.15 & 4.22 & 10.67 & 11.12 & 2.5 & 2.87 \\
\hline F. test & $* *$ & $* *$ & $* *$ & $* *$ & $* *$ & $* *$ \\
\hline L.S.D 5\% & 0.37 & 0.22 & 0.42 & 0.34 & 0.13 & 0.12 \\
\hline
\end{tabular}

TABLE 6. Economic estimation of cucumber foliar spray with some biostimulants, microorganisms and their mixture.

\begin{tabular}{|l|c|c|c|c|c|c|}
\hline \multicolumn{1}{|c|}{ Treatments } & $\begin{array}{c}\text { Fruit } \\
\text { yield } \\
\text { (t/fed.) }\end{array}$ & $\begin{array}{c}\text { Price } \\
\text { (L.E.) }\end{array}$ & $\begin{array}{c}\text { Fixed } \\
\text { costs } \\
\text { (L.E.) }\end{array}$ & $\begin{array}{c}\text { Changed } \\
\text { costs } \\
\text { (L.E.) }\end{array}$ & $\begin{array}{c}\text { Total } \\
\text { costs } \\
\text { (L.E.) }\end{array}$ & $\begin{array}{c}\text { Net } \\
\text { return } \\
\text { (L.E.) }\end{array}$ \\
\hline Compost tea extract & 13.02 & 16275 & 11750 & 150 & 11900 & 4375 \\
\hline Seaweed extract & 10.79 & 13488 & 11750 & 200 & 11950 & 1538 \\
\hline Fishmeal extract & 10.48 & 13100 & 11750 & 50 & 11800 & 1300 \\
\hline Azospirillum liquid & 12.20 & 15250 & 11750 & 300 & 12050 & 3200 \\
\hline Trichoderma liquid & 10.22 & 12775 & 11750 & 300 & 12050 & 725 \\
\hline Mixture & 15.10 & 18875 & 11750 & 200 & 11950 & 6925 \\
\hline Control & 9.59 & 11988 & 11750 & - & 11750 & 238 \\
\hline
\end{tabular}

- Fixed costs (L.E.) includes, rent of field (3000), Ploughing (150), nurses (4000), pesticides (500), organic fertilizers (1500), mineral fertilizers (800), irrigation (300), harvesting (1500).

- Price of cucumber (1250 L.E. / ton).

\section{Conclusion}

It can be recommended that all applied of biostimulants and/or some growth promoting rhizobacteria had positive and promoting effects on cucumber plants growth. The results of the present investigation indicated that, foliar application of mixture, compost tea extract, seaweed extract, fishmeal extract and effective bacteria were superior effect on vegetative growth characters and some chemical compounds of fruits of cucumber plants. Also, foliar application led to producing higher total yield with best quality of cucumber fruits. It could be concluded that, mixture more effective treatment than other treatments for yield and quality of cucumber under the experimental conditions. 


\section{References}

A.O.A.C. (1965) Official Methods of Analysis, the association of official agriculture chemists, $10^{\text {th }}$ ed., Washington D.C., U.S.A.

Abbasi, P.A., Al-Dahmani, J., Sahin, F., Hoitink, H.A.J. and Miller, S.A. (2002) Effect of compost amendments on disease severity and yield of tomato in conventional and organic production systems. Plant Dis., 86, 156-161.

Abou-El-Hassan, S. and Desoky, A.H. (2013) Effect of compost and compost tea on organic production of head lettuce. J. Appl. Sci. Res., 9(11), 5650-5655.

Abou-El-Hassan, S., Abdrabbo, M.A. and Desoky, A.H. (2014) Enhancing Organic Production of Cucumber by using Plant Growth Promoting Rhizobacteria and Compost Tea under Sandy Soil Condition. Research J. Agric. Bio. Sci., 10(2), 162169.

Allen, O.N. (1959) Experiments in Soil Bacteriology, Burgess Pub. Co., Ninn, Minnesota.

Biocycle, (2004) Bulding a knowledge base for compost tea. J. Composting and Organic Recycling, June, 1-2.

Brown, J.D. and Lilliland, O. (1946) Rapid determination of potassium and sodium in plant material and soils extracts by flam-photometry, Proc. Amer. Soc. Hort. Sci., 48,341-346.

Chamangasht, S., Ardakani, M.R., Khavazi, K., Abbaszadeh, B. and Mafakheri, S. (2012) Improving Lettuce Growth and Yield by the Application of Biofertilizers. Scholars Research Library, ISSN 0976-1233 CODEN (USA): ABRNBW, Annals of Biological Research, 3(4), 1876-1879.

Döbereiner, J., Marrial, L.E. and Nery, M. (1976) Ecological distribution of Spirillum lipoferum. Beigerink. Can. J. Microbiol., 22, 1464-1473.

Eissa, Fawzia, M. (2003) Effect of biostimulants on vegetative growth, yield and fruit quality of "Kelsey" Plum. Egypt. J. Appl. Sci., 18, 716-735.

El-Desouky, S.A., Ismaeil, F.H., Wanas, A.L., Fathy, E.S.L. and AbdEl-All, M.M. (2011). Effect of yeast extract, amino acids and citric acid on physioanatomical aspects and productivity of tomato plants grown in late summer season. Minufiya $J$. Agric. Res., 36(4), 859-884.

FAO/TTC (2001) World markets for organic fruits and vegetables: opportunities for developing countries in the production and export of organic horticultural products, (TC/D/Y1669E/9.01/6730).

Fathy, S. L., Farid, S. and El-Desouky, S.A. (2000) Induce cold tolerance of outdoor tomatoes during early summer season by using ATP, yeast, other natural and chemical treatments to improve their fruiting and yield. J. Agric. Sci. Mansoura Univ., 25(1), $377-401$.

Egypt. J. Hort. Vol. 42, No. 1 (2015) 
Fornes, F., Sánchez-Perales, M. and Guadiola, J.L. (2002) Effect of a seaweed extract on the productivity of 'de Nules' Clementine mandarin and navelina orange. Botanica Marina, 45, 486-489.

Haikal nahed, Z. (2008) Control of Rhizoctonia solani in Soybean (Glycine max L.) by seed-coating with Trichoderma viride and Gliocladium virens spores. J. Appl. Biosci., 1(2), 34 - 39 .

IFAOM/SOEL (2000) World organic agriculture report.

Ingham, E.R. (2005) The Compost Tea Brewing Manual, Latest Methods and Research. $5^{\text {th }}$ ed., Soil Food Web Inc., Corvallis, Oregon, USA.

Khan, W., Rayirath, U.P., Subramanian, S., Jithesh, M.N., Rayorath, P., Hodges, D.M., Critchley, A.T., Craigie, J.S., Norrie, J. and Prithivira, B. (2009) Seaweed extracts as biostimulants of plant growth and development. J. Plant Growth Regul., 28, 386-399.

Martinez-Viveros, O., Jorquera, M.A., Crowley, D.E., Gajardo, G. and Mara, M.L. (2010) Mechanism and practical considerations involved in plant growth promotion by rhizobacteria. J. Soil Sci. Plant Nutr., 10(3), 293-319.

Masarirambi, M.T., M.M. Hlawe, O.T. Oseni and T.E. Sibiya (2010) Effects of organic fertilizers on growth, yield, quality and sensory evaluation of red lettuce (Lactuca sativa L.) Veneza Roxa. Agric. Biol. J. N. America, 1(6), 1319-1324.

Meshref, H.A., Rabie, M.H., El-Ghamry, A.M. and El-Agamy, M.A. (2010) Maximizing utilization of compost addition using foliar compost extract and humic substances in alluvial soil. J. Soil Sci. and Agric. Engineering, Mansoura Univ., 1(9), 957-971.

Nour El-Din, M. (2006) Influence of foliar application with some micronutrients and some microorganisms on growth of peanut plant. Alex. J. Agric. Res., 51,113-119.

Pregl, F. (1945) "Quantitative Organic Microanalysis" $4^{\text {th }}$ ed., J. A. Churchill Ltd. London.

Recycled Organics Unit (2003b) Buyers's guide for recycled organics products. Information sheet 5-6. Recycled organics product categories and standards. Recycled Organics Unit, internet publication: www.recycledorganics.com

Saharan, B.S. and Nehra, V. (2011) Plant Growth Promoting Rhizobacteria: A Critical Review. Life Sciences and Medicine Research, 21.

Shehata, S. M., Abdel-Azem, H.S., Abou El-Yazied, H.S. and A. M. El-Gizawy (2011) Effect of foliar spraying with amino acids and seaweed extract on growth chemical constitutes, yield and its quality of celeriac plant. European J. of Sci. Res., 58(2), 257265.

Snedecor, G.W. and Cochran, W.G. (1972) Statistical Methods, $7^{\text {th }}$ ed., Iowa State Univ. Press, Ames, Iowa, USA. 
Taso, P.H. (1970) Selective media for isolation of pathogenic fungi. Ann. Rev. Phylopathol., 8,157-186.

Thoa, D.K. (1998) Cucumber seed multiplication and characterization. AVRDC/ARC Training Thailand.

Trough, E. and Mager, A.H. (1939) Improvement in deiness colorimetric method for phosphorus and arsenic. Ind. En. Chemical Anal. Ed., 1, 136-139.

Wehner, T.C. and Guner, N. (2004) Growth stage, flowering pattern, yield and harvest date prediction of four types of cucumber tested at 10 planting dates. Proc. xxvi IHC. Advances in Vegetable Breeding, J.D. Mc Creight and E.J. Ryder, (Ed.) Acta. Hort., 637, ISHS.

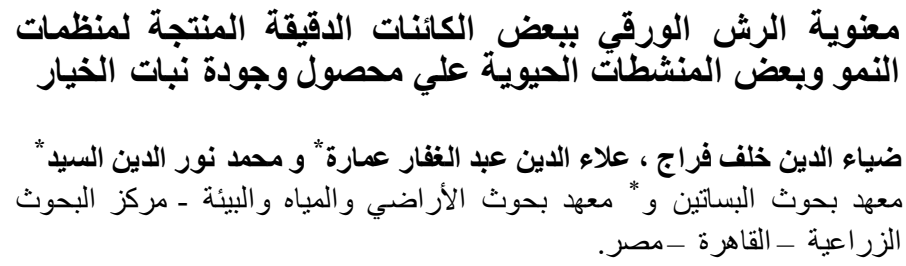

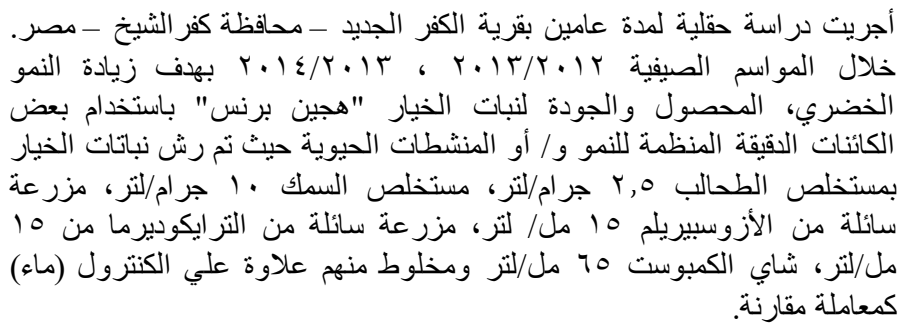

و أجري الرش بهذه المعاملات المختلفة بعد 10 يوم من الثتل ثم الرش مرثنين

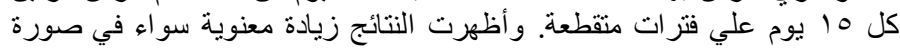

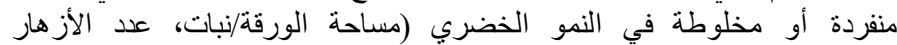

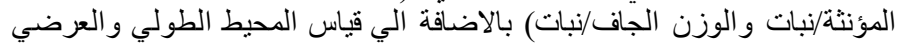

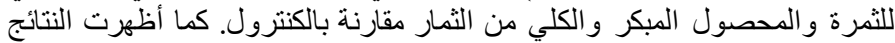

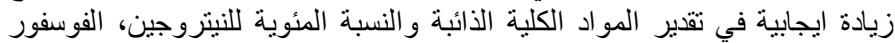

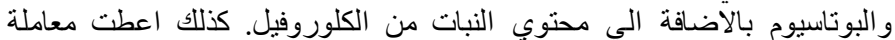

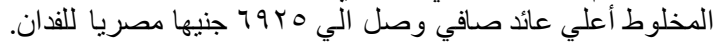

وتوصي الدراسة باستخدام معاملة المخلوط من الكائنات الدقيقة المنتجة

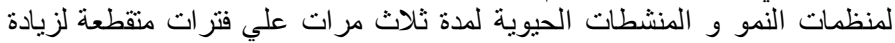
المحصول وصفات الجودة لنبات الخيار.

Egypt. J. Hort. Vol. 42, No. 1 (2015) 